Article

\title{
Pressurized Liquid Extraction (PLE) as an Innovative Green Technology for the Effective Enrichment of Galician Algae Extracts with High Quality Fatty Acids and Antimicrobial and Antioxidant Properties
}

\author{
Paz Otero *, Somaris E. Quintana, Guillermo Reglero, Tiziana Fornari and Mónica R. García-Risco \\ Research Institute of Food Science (CSIC-UAM). C/Nicolás Cabrera 9, Autonomous University of Madrid, \\ 28049 Madrid, Spain; somaris.quintana@predoc.uam.es (S.E.Q.); guillermo.reglero@uam.es (G.R.); \\ tiziana.fornari@uam.es (T.F.); monica.rodriguez@uam.es (M.R.G.-R.) \\ * Correspondence: paz.otero@uam.es
}

Received: 4 April 2018; Accepted: 8 May 2018; Published: 10 May 2018

\begin{abstract}
Marine organisms are potentially prolific sources of high qualify fatty acids that represent useful leads in the development of new nutraceutical agents. In this work, we investigated the lipid composition of six algae species from the Northwest of Spain (Ulva intestinalis, Ulva lactuca, Fucus vesiculosus, Dictyota dichotoma, Cystoseira baccata and Himanthalia elongata) and compared the antioxidant and antibacterial activity of ethanolic extracts obtained by pressurized liquid extraction (PLE). Furthermore, Fucus vesiculosus (F. vesiculosus) PLE using five solvents of different polarities (hexane, ethyl acetate, acetone, ethanol and ethanol:water 50:50) at three temperatures $\left(80^{\circ} \mathrm{C}\right.$, $120{ }^{\circ} \mathrm{C}$ and $160^{\circ} \mathrm{C}$ ) was investigated. F. vesiculosus ethanolic PLE extract presents considerably higher capacity of inhibiting 50\% of DPPH (1,1-diphenyl-2-picryl hydrazyl) $\left(\mathrm{IC}_{50}=7.17 \mu \mathrm{g} / \mathrm{mL}\right)$ in comparison with the rest of macroalgae studied. Moreover, the potential antimicrobial activity tested on E. coli and S. aureus shows that $F$. vesiculosus extract produced the best inhibition $\left(\mathrm{IC}_{50}\right.$ was $2.24 \mathrm{mg} / \mathrm{mL}$ (E. coli) and $1.27 \mathrm{mg} / \mathrm{mL}$ (S. aureus)). Furthermore, regarding the different solvents and temperatures used to investigate $F$. vesiculosus PLE, results showed that this technique using ethyl acetate is a selective method to enrich long chain fatty acids (oleic acid, arachidonic acid and eicosapentaenoic acid) with $\omega-6 / \omega-3$ ratios close to 2.7 .
\end{abstract}

Keywords: macroalgae; Fucus vesiculosus; fatty acids; pressurized liquid extraction (PLE); gas chromatography-mass spectrometry (GC-MS)

\section{Introduction}

The economic potential of the algae industry is widely recognized. Algae have been consumed for many years in Asian countries and their bioactives have recently gained a considerable interest due to their multiple applications in the food and pharmaceutical industries [1-3]. Two major types of marine algae can be identified: the macroalgae or seaweeds occuping the littoral zone, which included green algae (Chlorophyceae), brown algae (Phaeophyceae) and red algae (Rhodophyceae), and the microalgae found in both benthic and littoral habitats and also throughout the ocean waters as phytoplankton [4].

Although algae consumption around the world has increased considerably mainly due to the Asian influence and its cuisine [5], in most developed countries, people dislike eating algae directly as food commodity due to their dirty image and the lack of reliability in regards to non-toxic products. Extracting algae compounds and using them as food ingredients increase consumer acceptance. Over the past decades, bioactive properties of algae components have been investigated and several 
algae extracts have been brought to the market as food supplements. For example, Solaray ${ }^{\circledR}$, a dietary supplement product containing the extract of the red marine algae Rhodymenia palmata is sold to maintain the health of the immune system; Omega 3 Vegan Lineavi, a product from Schizochytrium sp. algae oil, provides a vegetarian and vegan friendly source of the healthy fats [6]. Omega-3 fatty acids are mainly found in unicellular phytoplankton and marine algae. Eicosapentaenoic acid (EPA) accumulates in fish and other marine animals that consume algae and get passed on to other species through the food chain $[7,8]$. These FAs have been found to have positive effects on the central nervous system for the development of brain, retinal and neural tissues in foetuses and young children [8]. Hence, the importance of algae as a source for high value FAs intended for nutrition is increasing rapidly and methods for maximum extraction and best determination of different fatty acid (FAs) in algae are needed.

Traditionally these lipids have been extracted using Solid-Liquid Extraction (SLE) methods based in chloroform:methanol in different proportions $[9,10]$, and subsequent FA profiling is carried out by LC-MS or GC-MS. Recently, acid-based extraction was used for improving the lipid yield of lipid-producing microalgae, being hypochlorous and sulphuric acids the most commonly used in an acid-catalysed hot-water extraction [11-14]. However, SLE is time-consuming, energy intensive and not in accordance with the current regulation about the use of permitted solvents in the production of foodstuffs and food ingredients [15]. Therefore, it is necessary to identify and develop new efficient extraction processes to exploit the bioactives present in marine algae. Extraction technologies such as Supercritical Fluid Extraction (SFE) and Ultrasonic Solvent Extraction (USE) have been investigated to extract these FAs $[16,17]$. Moreover, PLE is currently considered an advanced technique since it offers important benefits such as shorter extraction time, decreased solvent consumption, decreased sample handling and increased yield [18]. Moreover, this technique is in line with the green aspects of sample preparation.

This work aims to study the FA content of macroalgae species originally from the Northwest of Spain, and to optimize the PLE technique for producing algae extracts with potential use as food supplements. In a first study, we compared the lipid content of four macroalgae Phaeophyta species, Fucus vesiculosus (F. vesiculosus), Dictyota dichotoma (D. dichotoma), Cystoseira baccata (C. baccata) and Himanthalia elongata (H. elongata) and two Chlorophyta species, Ulva intestinalis (U. intestinalis) and Ulva lactuca (U. lactuca). Moreover, ethanolic PLE extracts of these six macroalgae were produced and their antioxidant and antibacterial capacity were also compared. In a second study, the PLE optimization for the extraction of FAs was investigated in F. vesiculosus. To our knowledge, no assessment on the effect of PLE extraction on lipid composition of macroalgae has been done so far. While a number of researches optimized PLE to extract carotenoids and phenolic compounds from algae [19-23], none have been reported about the use of PLE to extract FAs from macroalgae.

\section{Results and Discussion}

\subsection{Comparison of Macroalgae Lipid Content}

The lipid content and FA profile of four brown species of macroalgae (F. vesiculosus, D. dichotoma, C. baccata and H. elongata) and two green algae (U. intestinalis, U. lactuca) were determined. Algae lipid fraction was extracted by Folch method and then, it was submitted to a trans-esterification step before being analysed by GC-MS. Table 1 shows the results obtained for the six macroalgae investigated. The lipid content ranged from $4.6 \%$ to $6.7 \%$ and, as expected, lower quantities were obtained for green algae. The six algae accumulated saturated FA (SFA) such as myristic (C14:0), palmitic (C16:0) and stearic (C18:0), but also unsaturated FA (USFA) like oleic (C18:1), linoleic (C18:2) and palmitoleic (C16:1). Besides, pentadecilic (C15:0) was detected in four species, $\gamma$-linolenic (C18:3) was identified in three species (F. vesiculosus, H. elongata, U. lactuca), ARA (C20:4) was detected in F. vesiculosus and C. baccata and EPA (C20:5) was detected in the F. vesiculosus, C. baccata and D. dichotoma. 
Table 1. Lipid content (\%) and fatty acid composition $(\mathrm{mg} / \mathrm{g})$ of 6 algae species (Dry Weight). Lipids were extracted using the Folch method $(n=3)$. Number of carbon and unsaturation $(\mathrm{C}: \mathrm{U})$ status and retention time (RT) of the fatty acid methyl esters (FAMEs) are also included. Results show mean \pm standard error of the mean (SEM) of three experiments. N.D means not detected.

\begin{tabular}{|c|c|c|c|c|c|c|c|c|}
\hline & FA (C:U) & RT (min) & F. vesiculosus & C. baccata & $\begin{array}{c}H . \\
\text { elongata }\end{array}$ & $\begin{array}{c}\text { D. } \\
\text { dichotoma }\end{array}$ & U. lactuca & $\begin{array}{c}U . \\
\text { intestinalis }\end{array}$ \\
\hline \multirow{6}{*}{$\begin{array}{l}\text { FA content } \\
\text { (mg/g algae) }\end{array}$} & FA 15:0 & 10.774 & $0.31 \pm 0.03$ & N.D & $0.17 \pm 0.03$ & N.D & $0.18 \pm 0.02$ & $0.08 \pm 0.00$ \\
\hline & FA 16:0 & 12.078 & $9.64 \pm 0.30$ & $6.80 \pm 0.29$ & $5.85 \pm 0.14$ & $4.40 \pm 0.64$ & $6.09 \pm 0.29$ & $6.02 \pm 0.22$ \\
\hline & FA 18:3 & 14.900 & $0.08 \pm 0.00$ & N.D & $0.04 \pm 0.04$ & N.D & $0.09 \pm 0.01$ & N.D \\
\hline & FA 18:2 & 15.304 & $0.34 \pm 0.04$ & $0.16 \pm 0.02$ & $0.01 \pm 0.00$ & $0.01 \pm 0.00$ & $0.05 \pm 0.01$ & $0.06 \pm 0.00$ \\
\hline & FA 20:4 & 20.549 & $1.30 \pm 0.12$ & $0.62 \pm 0.01$ & N.D & N.D & N.D & N.D \\
\hline & FA 20:5 & 20.806 & $0.36 \pm 0.08$ & $0.24 \pm 0.01$ & N.D & $0.15 \pm 0.03$ & N.D & N.D \\
\hline \multicolumn{2}{|c|}{ FA total (mg/g algae) } & & 38.83 & 19.87 & 10.64 & 11.09 & 10.46 & 10.63 \\
\hline \multicolumn{2}{|c|}{ Lipid content by Folch (\%) } & & $6.6 \%$ & $6.7 \%$ & $6.0 \%$ & $5.7 \%$ & $4.8 \%$ & $4.6 \%$ \\
\hline
\end{tabular}

The FA profiles found in the six alga species are in accordance with the profiles found in previous studies [2,24]. Schmid and Stengel studied the FA content (\%) of H. elongata collected in the Irish Coast [24]. Besides palmitic acid (C16:0) (23.6\%), the algae produce high content of ARA (C20:4) $(16.6 \%)$ stearidonic acid (C18:4), $\gamma$-linolenic acid (C18:3) $(10.7 \%)$, oleic acid (C18:1) $(10.6 \%)$ and EPA $(C 20 ; 5)$ $(10.2 \%)$. Andrade and co-workers investigated the FA profile of algae species belonging to genus Fucus, Cystoseira and Ulva (F. spiralis, C. tamariscifolia, C. usneoides, C. nodicaulis and U. lactuca) from the West Coast of Portugal [2]. In general, FA profiles found in Fucus species are similar in both Portuguese and Galician algae species. The major fatty acid was oleic acid (C18:1) and the amounts were $21.69 \mathrm{mg} / \mathrm{g}$ (F. spiralis) and $13.15 \mathrm{mg} / \mathrm{g}$ (F. vesiculosus). Similarly, the major FA found in Ulva and Cystoseira species was palmitic acid (C16:0) and the amounts were $0.38 \mathrm{mg} / \mathrm{g}$ (U. lactuca Portuguese specie), $6.09 \mathrm{mg} / \mathrm{g}$ (U. lactuca Galician specie), $6.02 \mathrm{mg} / \mathrm{g}$ (U. intestinalis), $6.80 \mathrm{mg} / \mathrm{g}$ (C. baccata), $0.29 \mathrm{mg} / \mathrm{g}$ (C. tamariscifolia), $0.20 \mathrm{mg} / \mathrm{g}$ (C. usneoides) and $0.09 \mathrm{mg} / \mathrm{g}$ (C. nodicaulis).

\subsection{Comparison of Antioxidant and Antibacterial Activities of Ethanolic PLE Macroalgae Extracts}

The antioxidant and antimicrobial activity of these macroalgae were also studied and compared. For this purpose, ethanolic PLE extracts were obtained at $120^{\circ} \mathrm{C}$. Antioxidant capacity was tested using the DPPH assay and results are shown in Table 2. The best dose-response activity was observed for $F$. vesiculosus followed by $C$. baccata and $H$. elongata with a capacity of inhibiting $50 \%$ of DPPH $\left(\mathrm{IC}_{50}\right)$ at $7.17 \pm 0.01 \mu \mathrm{g} / \mathrm{mL}$ (F. vesiculosus), $28.49 \pm 3.80 \mu \mathrm{g} / \mathrm{mL}$ (C. baccata) and $64.89 \pm 6.64 \mu \mathrm{g} / \mathrm{mL}$ (H. elongata). Our results concord with previous studies which describe green algae have lower free radical scavenging activities when compared to brown algae [25-27]. While high $\mathrm{IC}_{50}$ values are found for pure or aqueous methanol extracts from Ulva species such as U. clathrata $(715 \mu \mathrm{g} / \mathrm{mL})$ [28], U. prolifera $(3026 \mu \mathrm{g} / \mathrm{mL})[28]$ and $U$. compresa $(>1000 \mu \mathrm{g} / \mathrm{mL})$ [26], low $\mathrm{IC}_{50}$ values are observed in pure or aqueous methanol/ethanol extracts from Cystoseira species like C. sedoides (27 $\mu \mathrm{g} / \mathrm{mL})$ [29], C. baccata $(28 \mu \mathrm{g} / \mathrm{mL})$, C. usneoides $(55 \mu \mathrm{g} / \mathrm{mL})$ [26], C. osmundacea $(69 \mu \mathrm{g} / \mathrm{mL})$ [27] and C. tamariscifolia $(109 \mu \mathrm{g} / \mathrm{mL})$ [26]. At the same time, the genus Fucus is more reactive than Cystoseira after being extracted with organic solvents. The $\mathrm{IC}_{50}$ values obtained by DPPH assay are about $5 \mu \mathrm{g} / \mathrm{mL}$ for F. distichus [30], $7 \mu \mathrm{g} / \mathrm{mL}$ for F. vesiculosus (from Galician Coast), 10-14 $\mu \mathrm{g} / \mathrm{mL}$ for F. vesiculosus (from French Coast) [31] and $178 \mu \mathrm{g} / \mathrm{mL}$ for F. spiralis [26]. Data regarding genus Himanthalia and Dyctiota are scarce in the literature. A recent study shows that despite $D$. dichotoma extracts does not produced any antioxidant activity by the DPPH assay, interestingly this alga has the higher anti-cancer activity out of 24 marine macroalga studied [32]. To conclude, results of the DPPH assay show large variation in free radical scavenging activity among the different macroalgae genera. However, the activity of the Fucus and Cystoseira extracts obtained by PLE in this study are comparable to those obtained by SLE described and referenced above. 
Table 2. Antiradical activity of macroalgae ethanolic extracts against DPPH. Results show mean \pm standard error of the mean (SEM) of three experiments.

\begin{tabular}{cc}
\hline & Antioxidant Capacity \\
\hline & $\mathrm{DPPH}\left(\mathrm{IC}_{50} ; \mu \mathrm{g} / \mathrm{mL}\right)$ \\
F. vesiculosus & $7.17 \pm 0.01$ \\
D. dichotoma & $>100$ \\
C. baccata & $28.49 \pm 3.80$ \\
H. elongata & $64.89 \pm 6.64$ \\
U. intestinalis & $>100$ \\
U. lactuca & $>100$ \\
\hline
\end{tabular}

The antimicrobial activity of the six extracts from Spanish species were tested for a Gram-negative bacteria, Escherichia coli (E. coli) and a Gram-positive bacteria, Staphylococcus aureus (S.aureus). Figure 1 shows the activity reported as \% of antimicrobial reduction against the controls. Despite the six species (Figure 1A-F) showed antimicrobial activity against tested organisms, F. vesiculosus (Figure 1A) followed by C. baccata (Figure 1B) showed the best results. F. vesiculosus extract $(2.5 \mathrm{mg} / \mathrm{mL}$ ), inhibited the grown of S. aureus and E. coli in $30.7 \%$ and $49.8 \%$, respectively. In parallel, C. baccata extract $(2.5 \mathrm{mg} / \mathrm{mL})$, inhibited the grown of the same pathogens in $58.8 \%$ (S. aureus) and $37.9 \%$ (E. coli) after $24 \mathrm{~h}$.

For these two algae, the inhibition concentration $\left(\mathrm{IC}_{50}\right)$ values were calculated and results are shown in Figure 2. F. vesiculosus produced the best inhibition, $\mathrm{IC}_{50}$ was $2.24 \mathrm{mg} / \mathrm{mL}$ (E. coli) and $1.27 \mathrm{mg} / \mathrm{mL}$ (S. aureus). Despite preliminary results showed that different species of algae have an antimicrobial potential especially against E. coli and S. aureus [33-35], there are no many studies about the antibacterial activity of seaweeds used in the present study. El-Amraoui and co-workers evaluated the antimicrobial activity of several macroalgae extracts from the Maroccan Atlantic Coast [36]. They also found that the brown algae belonging to genus Cystoseira and Fucus (C. brachycarpa, C. compressa, F. vesiculosus) together with the red alga Gelidium sesquipedale had the best antimicrobial activity out of ten tested species (SLE with ethanol). Gupta et al. [37] evaluated the antibacterial activity of the edible Irish brown seaweeds H. elongata, Saccharina latissimi and Laminaria digitata. Their activity was tested against pathogens which commonly cause problems in the food industry, Listeria monocytogenes, Salmonella abony, Enterococcus faecalis and Pseudomonas aeruginosa. Methanol extracts of raw H. elongata $(60 \mathrm{mg} / \mathrm{mL})$ inhibited Listeria moncytogenes by $98.7 \%$ compared to $96.5 \%$ inhibition by the synthetic preservative standard sodium benzoate and sodium nitrite $(96.2 \%)$. In our study, we used PLE extracts of H. elongata 24 times less concentrated $(2.5 \mathrm{mg} / \mathrm{mL})$ and they inhibited $38 \%$ S. aureus growth and $22 \%$ E. coli growth. Previous studies have demonstrated that algae can produce a wide variety of metabolites as defences against herbivory as well as to prevent biofouling [38]. The substances isolated from macroalgae showing potent antimicrobial activity belong to polysaccharides, FA, phlorotannins, pigments, lectins, alkaloids, terpenoids and halogenated compounds [39,40], hence several compounds are involved in this activity including FA [33]. Moreover, the chemical composition of the algae and the antimicrobial activities vary with environmental conditions of the growth including light, temperature or salinity and geographical location and seasonality [40]. To summarize, the present finding brings out a new insight towards the possible development of antimicrobials against Gram-negative and Gram-positive bacteria based on F. vesiculosus and C. baccata natural products obtained by PLE green technology. 
A

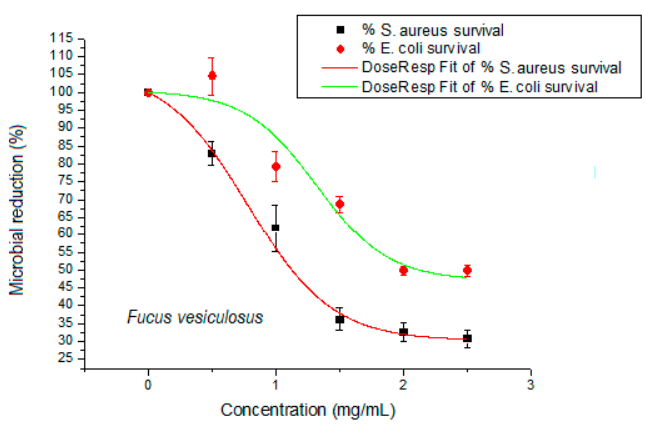

C

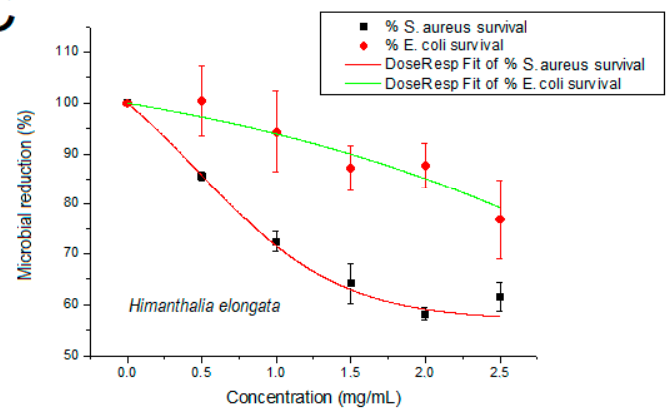

E

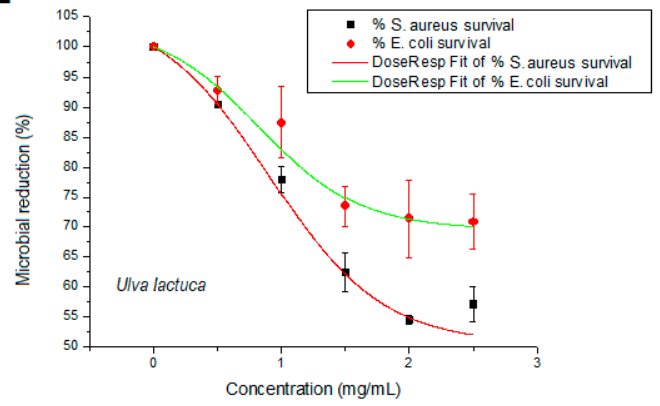

B

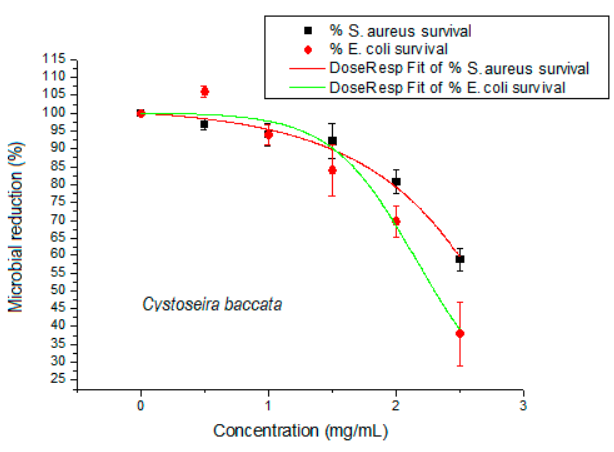

D

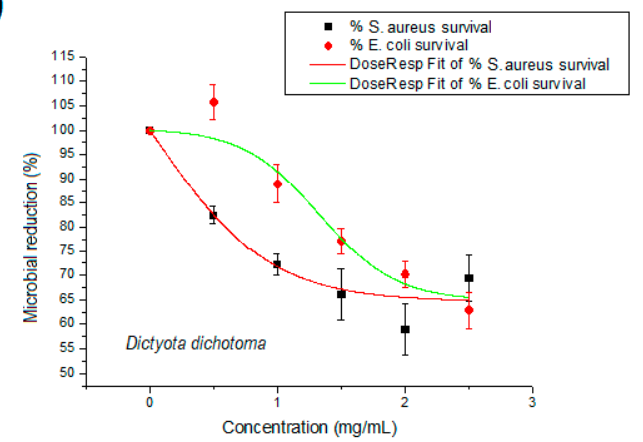

F

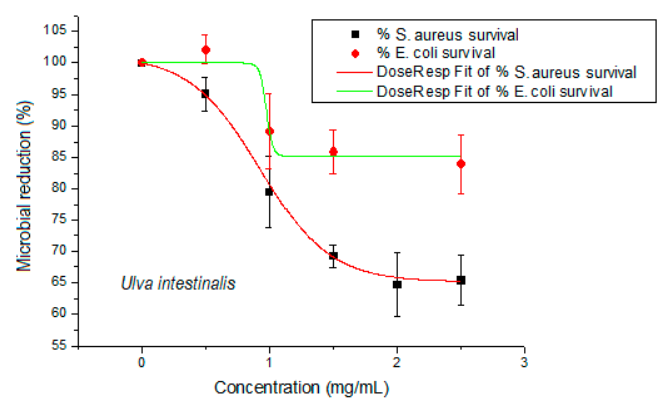

Figure 1. Antimicrobial activity of the PLE ethanoic extracts seaweeds against the two pathogenic bacterial strains. The activity is reported as \% of antimicrobial reduction against the controls and each graph correspond to Fucus vesiculosus (A), Cystoseira baccata (B), Himanthalia elongata (C), Dictyota dichotoma (D), Ulva lactuca (E) and Ulva intestinalis (F) PLE extracts. Results show mean \pm standard error of the mean (SEM) of three experiments. 
A

Fucus vesiculosus

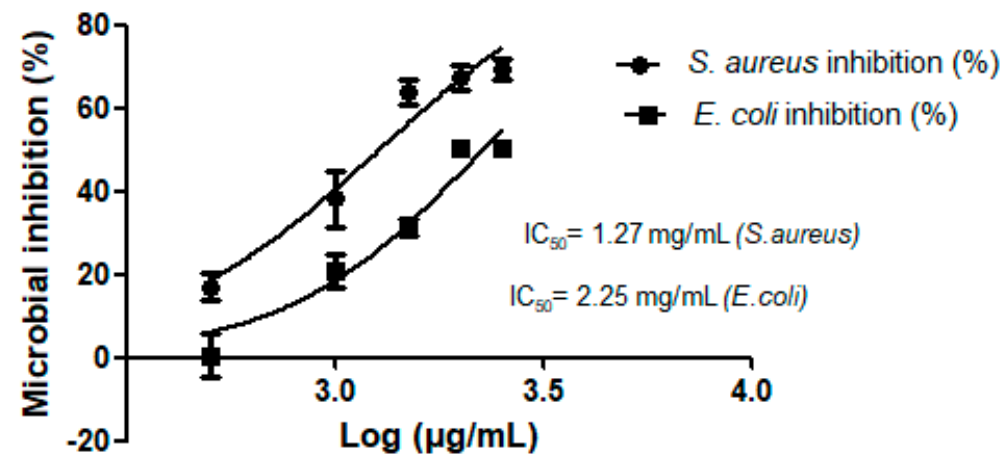

B

Cystoseira baccata

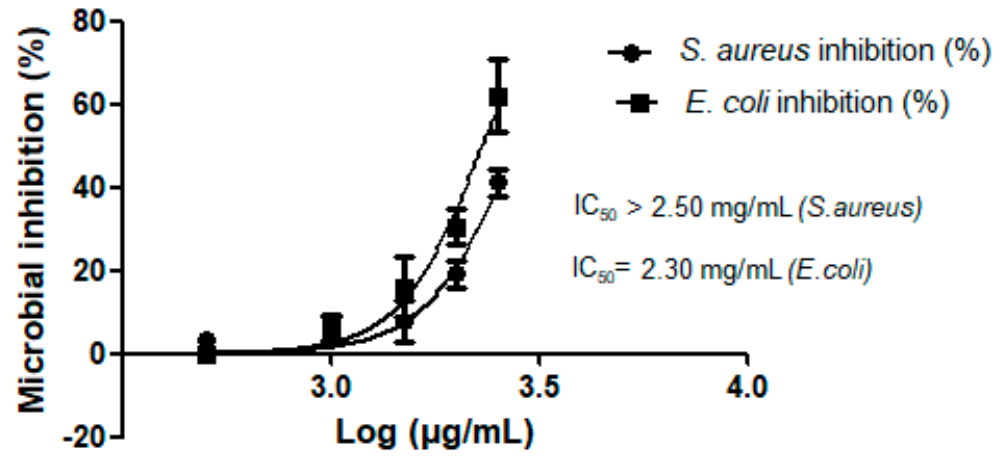

Figure 2. Antimicrobial activity of the PLE ethanoic extracts F.vesiculosus (A) and C. baccata (B) against the two pathogenic bacterial strains. Results show mean \pm standard error of the mean (SEM) of three experiments.

\subsection{Effect of PLE on the Lipid Composition of F. vesiculosus Extract}

According to the results of Section 2.1, F. vesiculosus accumulated the biggest number and quantities of FAs, thus the effect on the lipid profile of different PLE conditions was investigated using this alga. Parameters that have a significant effect on PLE efficiency were investigated, including solvent type and temperature. Precisely, $1 \mathrm{~g}$ of F. vesiculosus algae powder was submitted to PLE using five different solvents (hexane, ethanol, ethyl acetate, acetone and ethanol:water 50:50) and three temperatures $\left(80^{\circ} \mathrm{C}, 120^{\circ} \mathrm{C}\right.$ and $\left.160{ }^{\circ} \mathrm{C}\right)$. The solvents used cover a wide range of dielectric constants, and therefore, able to extract bioactives of different polarity. After 10 min extraction, the resulting extracts were collected, dried and weight in order to determine the yield. Table 3 shows the yields obtained for each experiment. Comparing solvents, the higher amounts were obtained for the most polar ones (ethanol:water 50:50, ethanol and acetone), while low yields were achieved with ethyl acetate and hexane. For example, at $120^{\circ} \mathrm{C}$ (intermediate extraction temperature tested) it was obtained $414.9 \pm 14.7 \mathrm{mg}$ (ethanol:water 50:50), $119.8 \pm 11.8 \mathrm{mg}$ (ethanol), $107.3 \pm 2.3 \mathrm{mg}$ (acetone), $55.9 \pm 2.1 \mathrm{mg}$ (ethyl acetate) and $37.2 \pm 2.4$ (hexane). As expected, the yield increased with the extraction temperature used in the PLE system [22], reaching the maximum amount at $160{ }^{\circ} \mathrm{C}$ with ethanol:water 50:50 (571.9 $\pm 23.8 \mathrm{mg})$. 
Table 3. Yields (\%) obtained for F. vesiculosus. Results show mean \pm standard error of the mean (SEM) of three experiments.

\begin{tabular}{cccccc}
\hline \multicolumn{5}{c}{ Fucus vesiculosus } \\
\hline \multirow{2}{*}{ Extraction Temp. } & \multicolumn{5}{c}{ Yield (\%) PLE } \\
\cline { 2 - 6 } & Hexane & Ethyl Acetate & Acetone & Ethanol & Ethanol:Water 50:50 \\
\hline $\mathbf{8 0}{ }^{\circ} \mathbf{C}$ & $2.79 \pm 0.12$ & $4.72 \pm 0.11$ & $9.01 \pm 1.24$ & $8.85 \pm 1.51$ & $34.85 \pm 3.11$ \\
$\mathbf{1 2 0}^{\circ} \mathbf{C}$ & $3.72 \pm 0.24$ & $5.59 \pm 0.21$ & $10.73 \pm 0.23$ & $11.98 \pm 1.18$ & $41.49 \pm 1.47$ \\
$\mathbf{1 6 0}{ }^{\circ} \mathbf{C}$ & $4.49 \pm 1.54$ & $7.03 \pm 1.79$ & $12.90 \pm 1.21$ & $12.89 \pm 0.68$ & $57.19 \pm 2.38$ \\
\hline
\end{tabular}

The FA profiles of the F. vesiculosus PLE extracts were determined by GC-MS. In the chromatograms it was possible to identify up to eleven FA, including ten previously detected using Folch extraction and eicosa-5,8,11-trienoic acid (mead acid) (C 20:3) in small quantities at the end of the chromatogram $(\mathrm{RT}=21.233)$.

In the range of temperature studied, FA profiles were rather similar, showing that lipid composition is not very affected by temperature (data not shown). Since yields obtained at $80{ }^{\circ} \mathrm{C}$ were lower and the intensity of peaks at $160^{\circ} \mathrm{C}$ were slightly lower than those at $120{ }^{\circ} \mathrm{C}$, we selected the intermedia temperature $120^{\circ} \mathrm{C}$ as an optimum temperature to obtain $F$. vesiculosus extracts with high lipid content. Figure 3 shows the chromatograms of F. vesiculosus PLE extracts obtained at $120{ }^{\circ} \mathrm{C}$ with hexane (A), ethyl acetate (B), acetone (C), ethanol (D) and ethanol:water 50:50 (E) and Table 4 shows the FA quantification. In general, the maximum FA content was achieved with ethyl acetate (693.20 mg total FA/g PLE), following by acetone (595.90 mg total FA/g PLE) and ethanol (554.42 mg total FA/g PLE). As expected, results showed that ethanol:water 50:50 (156.23 mg total FA/g PLE) is not a proper solvent for fatty acid extraction from algae and, surprisingly, hexane (426.12 $\mathrm{mg}$ total FA/g PLE) did not improve the FA extraction with regards to acetone or ethanol. Comparing the FA profiles obtained with the different solvents, FA proportions were different depending on the solvent used (see Figure 3 and Table 4). For example, ethyl acetate enhanced oleic (C 18:1, peak 8), ARA (C 20:4, peak 10) and EPA (C 20:5, peak 11) with regards to acetone and ethanol since quantities were almost double. However, ethyl acetate did not enhance myristic (C 14:0, peak 2) and palmitic (C 16:0, peak 5) acids. The compounds enhanced correspond with the long chain FAs since they are less soluble in polar solvents than short chain FAs.

Table 4. Fatty acid composition (mg/g PLE extract) of lipids extracted by PLE from F. vesiculosus algae with 5 solvents (hexane, ethyl acetate, acetone, ethanol and ethanol:water 50:50) at $120{ }^{\circ} \mathrm{C}$. Results show mean \pm standard error of the mean (SEM) of three experiments. N.D means not detected.

\begin{tabular}{|c|c|c|c|c|c|}
\hline \multicolumn{6}{|c|}{ Fucus vesiculosus } \\
\hline \multirow{2}{*}{ FA } & \multicolumn{5}{|c|}{ FA Quantity (mg/g PLE) } \\
\hline & Hexane & Ethyl Acetate & Acetone & Ethanol & Ethanol:Water 50:50 \\
\hline FA 14:0 & $150.51 \pm 9.83$ & $227.31 \pm 9.43$ & $247.35 \pm 5.07$ & $211.62 \pm 5.19$ & $29.36 \pm 0.52$ \\
\hline FA 15:0 & $2.53 \pm 0.15$ & $3.8 \pm 0.42$ & $2.97 \pm 0.25$ & $2.91 \pm 0.11$ & $0.12 \pm 0.00$ \\
\hline FA $16: 1$ & $10.67 \pm 0.27$ & $14.21 \pm 0.60$ & $14.78 \pm 0.56$ & $13.33 \pm 0.5$ & $1.89 \pm 0.05$ \\
\hline FA 16:0 & $91.37 \pm 8.55$ & $150.37 \pm 6.01$ & $167.51 \pm 7.42$ & $159.16 \pm 14.68$ & $84.98 \pm 2.04$ \\
\hline FA $18: 3$ & $0.16 \pm 0.27$ & $0.71 \pm 0.12$ & $0.39 \pm 0.01$ & $0.46 \pm 0.07$ & N.D \\
\hline FA 18:2 & $3.76 \pm 0.32$ & $6.18 \pm 0.17$ & $3.58 \pm 0.02$ & $3.47 \pm 0.64$ & $0.45 \pm 0.02$ \\
\hline FA $18: 1$ & $131.52 \pm 10.54$ & $234.44 \pm 6.62$ & $123.19 \pm 28.83$ & $126.11 \pm 8.48$ & $18.33 \pm 0.32$ \\
\hline FA 18:0 & $12.22 \pm 1.46$ & $19.75 \pm 0.77$ & $16.91 \pm 1.21$ & $16.92 \pm 1.62$ & $16.43 \pm 0.22$ \\
\hline FA 20:4 & $15.65 \pm 1.49$ & $23.38 \pm 0.82$ & $11.41 \pm 0.01$ & $13.02 \pm 2.29$ & $2.92 \pm 0.04$ \\
\hline FA 20:5 & $6.63 \pm 0.66$ & $11.37 \pm 0.39$ & $6.94 \pm 0.47$ & $7.68 \pm 0.58$ & $1.75 \pm 0.02$ \\
\hline FA 20:3 & $1.10 \pm 0.10$ & $1.68 \pm 0.30$ & $0.87 \pm 0.05$ & $0.91 \pm 0.97$ & N.D \\
\hline Total FA & 426.12 & 693.20 & 595.90 & 554.42 & 156.23 \\
\hline Total $\omega-3$ & 6.63 & 11.37 & 6.94 & 7.68 & 1.75 \\
\hline Total $\omega-6$ & 19.57 & 30.27 & 15.38 & 17.43 & 3.37 \\
\hline ratio $\omega-6 / \omega-3$ & 2.95 & 2.665 & 2.215 & 2.208 & 1.92 \\
\hline
\end{tabular}



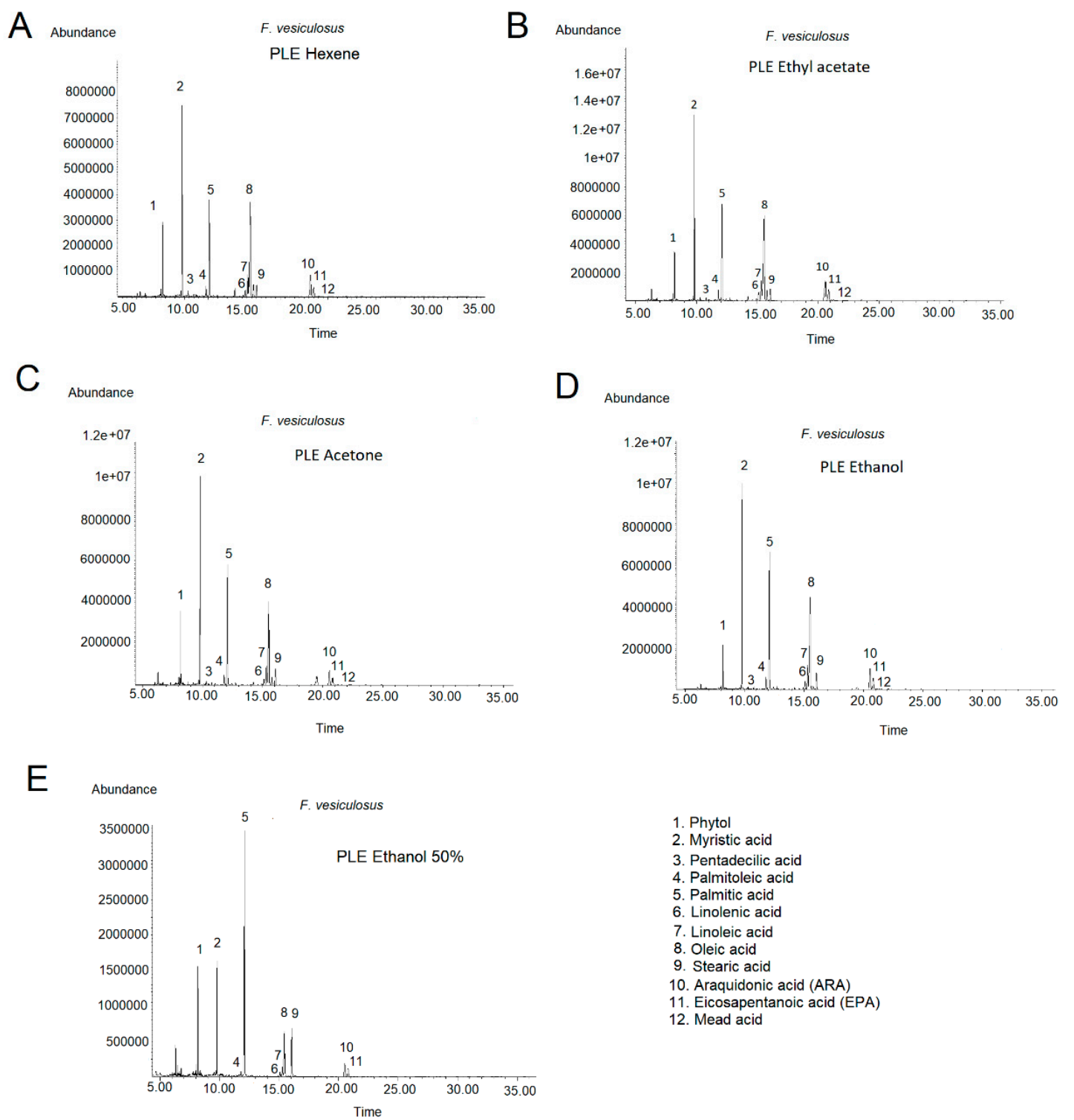

Figure 3. GC-MS chromatograms of Fucus vesiculosus extracted by PLE at $120{ }^{\circ} \mathrm{C}$ with hexane (A), ethyl acetate (B), acetone (C), ethanol (D) and ethanol:water 50:50 (E). The column used for FAMEs separation was an Agilent HP-5MS UI capillary column $(30 \mathrm{~m} \times 0.250 \mathrm{~mm} \times 0.25 \mu \mathrm{m})$ and the oven temperature programme started at $50{ }^{\circ} \mathrm{C}$, increased to $210^{\circ} \mathrm{C}$ at $20^{\circ} \mathrm{C}$ increase per min and hold for $18 \mathrm{~min}$. Then, temperature was further increased to $230^{\circ} \mathrm{C}$ at $20^{\circ} \mathrm{C}$ increase per min and kept at $230{ }^{\circ} \mathrm{C}$ for $13 \mathrm{~min}$.

Other authors have used SLE and/or PLE with solvents of different polarity for the extraction of FAs from food matrix and microalgae. Castejón and co-workers did not observe significant changes in the composition of chia seed oils extracted with solvents with different polarity [41]. Similarly, da Costa Rodriguez research group studied the effect of solvent composition of rice bran oil extracted with ethanol containing different water contents at $60-90^{\circ} \mathrm{C}$ and concluded that there were no major differences in the lipid composition present in the extracts [42]. The use of PLE with green solvents (water and ethanol) for the extraction of bioactives from the microalgae Nannochloropsis gaditana and Phaeodactylum tricornutum was recently investigated [43,44]. Despite the optimum extraction conditions was achieved with pure ethanol, FAs such as palmitoleic, palmitic, myristic acids and EPA were predominant in all PLE extracts from Nannochloropsis gaditana [43]. The PLE of F. vesiculosus algae carried out in this work showed that different solvents produced extracts with different FAs content 
and therefore, the possibility of using PLE as a selective technique for the extraction of specific carbon number fatty acids.

Furthermore, the differences in the FAs content in F. vesiculosus PLE extracts have a direct effect on the $\omega-6 / \omega-3$ ratio. The omega 6 to omega 3 FAs $(\omega-6 / \omega-3)$ ratio is another commonly used index to access healthy diet and thus, good lipid quality [24]. Studies have suggested that a high $\omega-6 / \omega-3$ ratio in diet is possibly linked to the development of a variety of physiological disorders (such as cancer, coronary heart disease, etc.) $[45,46]$. Table 4 shows that the $\omega-6 / \omega-3$ ratios in F. vesiculosus PLE extracts are between 2.95 (PLE ethyl acetate) and 1.92 (PLE ethanol:water 50:50) and represent ratios much lower than those recommended by FAO $(\omega-6 / \omega-3=10)$ [47]. These good values arise due to F. vesiculosus is able to synthetize high EPA content. However, although all fractions showed a low $\omega-6 / \omega-3$ FA ratio, the better value was obtained for extractions performed with the most polar solvents such as ethanol or ethanol:water 50:50. To summarize, F. vesiculosus PLE using ethyl acetate resulted in high lipid yield, improves the extraction efficiency for long chain fatty acids (oleic acid, ARA and EPA) and resulted extract contain lower $\omega-6 / \omega-3$ fatty acids ratio than the maximum recommended by FAO.

\section{Material and Methods}

\subsection{Sample Collection and Preparation}

Four brown species of marine algae (F. vesiculosus, D. dichotoma, C. baccata, H. elongata) and two green algae species (U. intestinalis, $U$. lactuca) were freshly collected during the low tide in June 2017 on the Atlantic coast of Galicia (Northwest of Spain). Samples were collected, kept in a polyethylene bags and transported to the laboratory immediately. Afterwards, algae were gently rinsed with distilled water, freeze-dried (LyoBeta 15, Telstar, Terrasa, Spain), grounded (particle size $<500 \mu \mathrm{m}$ ) (Knife Mill Grindomix GM 200, Retsch GmbH, Haan, Germany) and stored four weeks protected from oxygen, light and moisture until use.

\subsection{Chemicals}

FA standards, linoleic acid, $\gamma$-linolenic acid, oleic acid, palmitic acid, stearic acid, myristic acid, cis-5,8,11,14,17-eicosapentaenoic acid (EPA) and arachidonic acid (ARA) were obtained from Sigma (Madrid, Spain). Ethanol and acetone was obtained from PanReac AppliChem ITW Reagents (Barcelona, Spain). Ethyl acetate, hexane, methanol and chloroform was obtained from Macron Fine Chemicals ${ }^{\mathrm{TM}}$ (Gliwice, Poland). All solvents used in this study were high-performance liquid-chromatography or analytical grade, and the water was distilled and processed through an ultrapure water system (Milli-Q Integral 3 Water Purification System, Millipore, Burlington, MA, USA).

\subsection{Lipid Extraction}

Extraction of lipids was done following the method mentioned by Folch et al. [9] and quantified gravimetrically. Briefly, $10 \mathrm{mg}$ of dry weight (DW) algae was soaked in $500 \mu \mathrm{L}$ of chloroform: methanol $(2: 1, v / v)$ and kept overnight at $4{ }^{\circ} \mathrm{C}$. Next day, algae was sonicated in an ultrasounds bath (Selecta-ultrasons) and mixed by vortex. To ensure complete extraction, another $1250 \mu \mathrm{L}$ of extraction solvent was added and vortexed. Later, $1300 \mu \mathrm{L}$ of Milli-Q water was added and the content was vortexed mildly to remove water-soluble impurities. Then, the tubes were centrifuged (4000 rpm, $4 \mathrm{~min}$ ) for the separation of two layers. Lower lipid phase was transferred carefully to a vial and dried in a fume hood. These dried lipids were then measured gravimetrically.

\subsection{Pressurized Liquid Extraction (PLE)}

Extractions of algae species were performed using an accelerated solvent extractor (ASE, 350, Dionex Corp, Sunnyvale, CA, USA) equipped with a solvent controlled unit. Five different solvents (hexane, ethanol, ethyl acetate, acetone and ethanol $50 \%$ ) at 3 different temperatures $\left(80^{\circ} \mathrm{C}, 120^{\circ} \mathrm{C}\right.$, 
$160^{\circ} \mathrm{C}$ ) were tested. Extractions were performed in triplicate in $10 \mathrm{~mL}$ extractions cells and 100 bar. The amount of $1 \mathrm{~g}$ of algae was loaded into the stainless steel cell with sea sand (thin grain, particle size 250-300 $\mu \mathrm{m}$, Sigma-Aldrich, Madrid, Spain) above and below the sample to avoid any void spaces. Then, the extraction cell was placed into the carrousel and the automatic extraction sequence began with the loading of the cell into the oven. When the cell was heated to the pre-set extraction temperature, the cell was pressurized for $10 \mathrm{~min}$ and then allowed to flow the extract into the collection vial. The solvent total volume used was $20 \mathrm{~mL}$.

\subsection{Fatty Acid Analysis (by GC-MS)}

Identification and quantification of FAs were performed by modified method of Miller and Berger [48] as mentioned in Saha et al. [49]. Briefly, a known amount of lipid and PLE samples were saponifed by boiling it with $1 \mathrm{~mL}$ of saponification reagent $(15 \mathrm{~g} \mathrm{NaOH}$ in $100 \mathrm{~mL}$ of 1:1 methanol: water) for $30 \mathrm{~min}$. The sample was then boiled in a water bath at $80^{\circ} \mathrm{C}$ for 20 min with $2 \mathrm{~mL}$ of methylation reagent (1:1.18 methanol: $6 \mathrm{~N} \mathrm{HCl})$. After cooling, $1 \mathrm{~mL}$ of extraction solvent (1:1 distilled hexane: anhydrous diethyl ether) was added and mixed thoroughly. Thereafter the lower aqueous phase was discarded and the remaining upper phase was washed with $3 \mathrm{~mL}$ of base wash solution $(1.2 \% \mathrm{NaOH} w / v)$. Finally, one aliquot of the resulting sample was dissolved in hexane to be analyzed by GC-MS. Standards were submitted to the same trans-esterification steps. Fatty acid methyl esters (FAMEs) were analysed by a GC-MS-FID using 7890A System (Agilent Technologies, (Loveland, CO 80537, USA) comprising a split/splitless injector, electronic pressure control G4513A autoinjector, a 5975C triple-axis mass spectrometer detector and GC-MS Solution software. The column used was an Agilent HP-5MS UI capillary column $(30 \mathrm{~m} \times 0.250 \mathrm{~mm} \times 0.25 \mu \mathrm{m})$. Helium was used as a carried gas at a constant flow of $1.8 \mathrm{~mL} / \mathrm{min}$. Oven temperature programme started at $50{ }^{\circ} \mathrm{C}$, increased to $210^{\circ} \mathrm{C}$ at $20^{\circ} \mathrm{C}$ increase per min and hold for $18 \mathrm{~min}$. Then, temperature was further increased to $230{ }^{\circ} \mathrm{C}$ at $20^{\circ} \mathrm{C}$ increase per min and kept at $230{ }^{\circ} \mathrm{C}$ for $13 \mathrm{~min}$. The injection volume was $1 \mu \mathrm{L}$ in splitless mode. Inlet temperatures was set at $260^{\circ} \mathrm{C}$ and MS ion source and interface temperatures were $230{ }^{\circ} \mathrm{C}$ and $280{ }^{\circ} \mathrm{C}$ respectively. Data were acquired in a full scan from 40 to $500 \mathrm{~m} / \mathrm{z}$.

\subsection{Antioxidant Activity}

The antioxidant activity of the PLE samples was determined by the DPPH scavenging assay based on a procedure described by Brand-Williams et al. [50]. This method consists in the neutralization of free radicals of DPPH (1,1-diphenyl-2-picryl hydrazyl) (Sigma-Aldrich, Spain) by the antioxidant extracts. A dilution series of the extracted samples was prepared $(0.25,0.5,1,1.5 \mathrm{mg} / \mathrm{mL})$ and an aliquot $(25 \mu \mathrm{L})$ of each one was added to $975 \mu \mathrm{L}$ of DPPH in ethanol $(23.5 \mu \mathrm{g} / \mathrm{mL})$. Reaction was complete after $2 \mathrm{~h}$ at room temperature in the dark. Absorbance was then measured at $515 \mathrm{~nm}$ against the blank in the Generys 10 uv spectrophotometer reader. Ethanol was used to adjust zero and DPPH-ethanol solution as a reference sample. The DPPH concentration in the reaction medium was calculated from the following calibration curve, determined by linear regression $(r=0.9998)$ : $\mathrm{Y}=0.0385 \mathrm{X}+0.0083$. The percentage of remaining DPPH against the extract concentration was then plotted to obtain the amount of antioxidant necessary to decrease the initial DPPH concentration by $50 \%$ or $\mathrm{IC}_{50}$. Thus, the lower the $\mathrm{IC}_{50}$, the higher the antioxidant power.

\subsection{Antibacterial Activity}

The PLE extracts were individually tested against a Gram-positive, S. aureus (ATCC 25923), and Gram-negative, E. coli (ATCC 25922), bacterial strains. All tests were performed in Mueller-Hinton broth supplemented with $0.5 \%$ tween 20 . The inocula of bacterial strains were prepared from overnight Mueller-Hinton broth cultures at $37^{\circ} \mathrm{C}$. Test strains were suspended in Mueller-Hinton broth to give a final density $1 \times 10^{8} \mathrm{cfu} / \mathrm{mL}$. The algae extract dilutions in ethanol ranged from 50 to $10 \mathrm{mg} / \mathrm{mL}$. The 96-microwell plates were prepared by dispensing into each well $185 \mu \mathrm{L}$ of culture broth, $5 \mu \mathrm{L}$ of the inocula and $10 \mu \mathrm{L}$ of the different extract dilution. The final volume of each well was $200 \mu \mathrm{L}$. Plates 
were incubated at $37^{\circ} \mathrm{C}$ for $24 \mathrm{~h}$ for each bacterium. Negative controls were prepared using $10 \mu \mathrm{L}$ of ethanol, the solvent used to dissolve the algae extracts. Chloramphenicol (Sigma, Madrid, Spain) were used as positive reference standards to determine the sensitivity of the microbial species used. Absorbance was then measured at $620 \mathrm{~nm}$ at initial time $(\mathrm{t}=0)$ and at $24 \mathrm{~h}(\mathrm{t}=24)$.

\subsection{Statistical Analysis}

Lipid and PLE extraction of algae, fatty acid GC-MS analysis, antioxidant and antibacterial determinations were performed in triplicates. Results are therefore averages of triplicates and the values in figures and tables are shown with the corresponding standard deviations.

\section{Conclusions}

In this study, we assessed the lipid composition, and the antioxidant and antibacterial activities of six macroalgae species from the Northwest of Spain (F. vesiculosus, D. dichotoma, C. baccata, H. elongata, $U$. intestinalis and $U$. lactuca). Results showed that F. vesiculosus followed by C. baccata are the best candidates to exploit them as a nutraceuticals or food products. To better exploit algae potential, there is a need to develop new and enhanced novel extraction technologies without the use of high amounts of toxic organic solvents. We used PLE technology as eco-friendly method to extract high quality lipid from $F$. vesiculosus algae. Effect of the extraction conditions on yield and FA composition of this alga was established. PLE optimization showed that lipid profile was not very influenced by temperature in the range studied $\left(80-160^{\circ} \mathrm{C}\right)$. After testing five different polarity solvents (hexane, ethanol, ethyl acetate, acetone and ethanol:water 50:50), we concluded that ethyl acetate enhances the extraction of long chain fatty acids (oleic acid, ARA and EPA), producing extracts with almost the double in comparison to ethanol and acetone solvents. Although the best (lower) $\omega-6 / \omega-3$ ratios were achieved with the most polar solvents, such as ethanol and ethanol:water 50:50, all $F$. vesiculosus PLE extracts showed $\omega-6 / \omega-3$ ratios lower than 3 , which are significantly lower than the maximum ratio recommended by FAO $(\omega-6 / \omega-3=10)$. Future research priorities in this area should be concentrated on overcoming the challenges of employing this PLE technique on an industrial scale so that the significant benefits to be obtained by improved extraction of FA from F. vesiculosus are exploited by industry.

Author Contributions: P.O. and S.E.Q. performed the antioxidant and antibacterial activity experiments. P.O. performed the PLE and GC-MS analysis. M.R. and P.O. analysed the data. T.F. and P.O. conceived and organized the manuscript and wrote the text. All authors (G.R., T.F., M.R.G.-R., P.O. and S.E.Q.) contributed to the critical revision of the paper.

Acknowledgments: This work was supported by the programme "Atracción de Talento 2016", Comunidad de Madrid (Spain). Paz Otero is recipient of Comunidad de Madrid Postdoctoral Funding (Grant No. 2016-T2/BIO-1791). Authors are also grateful to project ALIBIRD-CM. S2013/ABI-2728 (2014-2018). Comunidad de Madrid.

Conflicts of Interest: The authors declare no conflict of interest.

\section{References}

1. Shanura Fernando, I.; Kim, M.; Son, K.T.; Jeong, Y.; Jeon, Y.-J. Antioxidant activity of marine algal polyphenolic compounds: A mechanistic approach. J. Med. Food 2016, 19, 615-628. [CrossRef] [PubMed]

2. Andrade, P.; Barbosa, M.; Matos, R.; Loes, G.; Vinholes, J.; Mouga, T.; Valentao, P. Valuable compounds in macroalge extracts. Food Chem. 2013, 138, 1819-1828. [CrossRef] [PubMed]

3. Otero, P.; Alfonso, A.; Alfonso, C.; Vieytes, M.R.; Louzao, M.C.; Botana, A.M.; Botana, L.M. New protocol to obtain spirolides from Alexandrium ostenfeldii cultures with high recovery and purity. Biomed. Chromatogr. 2010, 24, 878-886. [PubMed]

4. Garson, J. Biosynthethic studies on marine natural products. Nat. Prod. Rep. 1989, 6, 143-170. [CrossRef]

5. Montero, L.; Sánchez-Camargo, A.; Ibáñez, E.; Gibert-López, B. Phenolic compounds from edible algae: Bioactivity and health benefits. Curr. Med. Chem. 2017, 24. [CrossRef] [PubMed] 
6. Li, D.; Zhang, K.; Chen, L.; Ding, M.; Zhao, M.; Chen, S. Selection of Schizochytrium limacinum mutants based on butanol tolerance. Electron. J. Biotechnol. 2017, 30, 58-63. [CrossRef]

7. Narayan, B.; Miyashita, K.; Hosakawa, M. Physiological effects of eicosapentaenoic acid (EPA) and docosahexaenoic acid (DHA) —A review. Food Rev. Int. 2006, 22, 291-307. [CrossRef]

8. Kadam, S.; Tiwari, B.; O'Donnell, C. Application of novel extraction technologies for bioactives from marine algae. J. Agric. Food Chem. 2013, 61, 4667-4675. [CrossRef] [PubMed]

9. Folch, J.; Lees, M.; Sloane-Stanley, G. A simple method for the isolation and purification of total lipids from animal tissues. J. Biol. Chem. 1957, 226, 497-509. [PubMed]

10. Bligh, E.; Dyer, W. A rapid method of total lipid extraction and purification. Can. J. Biochem. Physiol. 1959, 37, 911-917. [CrossRef] [PubMed]

11. Choi, S.-A.; Jung, J.-Y.; Kim, K.; Lee, J.-S.; Kwon, J.-H.; Kim, S.; Yang, J.-W.; Park, J.-Y. Acid-catalyzed hot-water extraction of docosahexaenoic acid (DHA)-rich lipids from Aurantiochytrium sp. KRS101. Bioresour. Technol. 2014, 161, 469-472. [CrossRef] [PubMed]

12. Park, J.Y.; Oh, Y.K.; Lee, J.S.; Lee, K.; Jeong, M.J.; Choi, S.A. Acid-catalyzed hot-water extraction of lipids from Chlorella vulgaris. Bioresour Technol. 2014, 153, 408-412. [CrossRef] [PubMed]

13. Park, J.-Y.; Choi, S.-A.; Jeong, M.-J.; Nam, B.; Oh, Y.-K.; Lee, J.-S. Changes in fatty acid composition of Chlorella vulgaris by hypochlorous acid. Bioresour. Technol. 2014, 162, 379-383. [CrossRef] [PubMed]

14. Otero, P.; Saha, S.K.; Mc Gushin, J.; Moane, S.; Barron, J.; Murray, P. Identification of optimun fatty acid extraction methods for two different microalgae Phaeodactylum tricornutum and Haematococcus pluvialis for food and biodiesel applications. Anal. Bioanal. Chem. 2017, 409, 4659-4667. [CrossRef] [PubMed]

15. European Commision. Directive 2009/32/EC of the European Parliament and of the Council of 23 April 2009 on the Approximation of the Laws of the Member States on Extraction Solvents Used in the Production of Foodstuffs and Food Ingredients; Official Journal of the European Union: Brussels, Belgum, 2009.

16. Cheung, P. Temperature and pressure effects on supercritical carbon dioxide extraction of n-3 fatty acids from red seaweed. Food Chem. 1999, 65, 399-403. [CrossRef]

17. Kumari, P.; Reddy, C.; Jha, B. Comparative evaluation and selection of a method for lipid and fatty acid extracion from macroalgae. Anal. Biochem. 2011, 415, 134-144. [CrossRef] [PubMed]

18. Rodrigues, E.; Pardal, M.; Salgueiro-González, N.; Muniategui-Lorenzo, S.; Alpendurada, M. A single-step pesticide extraction and clean-up multi-residue analytical method by selective pressurized liquid extraction followed by on-line solid phase extraction and ultra-high-performance liquid chromatography-tandem mass spectrometry for complex matrices. J. Chromatogr. A 2016, 1452, 10-17. [PubMed]

19. Shang, Y.; Kim, S.M.; Lee, W.; Um, B. Pressurized liquid method for fucoxanthin extraction from Eisenia bicyclis (Kjellman) Setchell. J. Biosci. Bioeng. 2011, 111, 237-241. [CrossRef] [PubMed]

20. Koo, S.; Cha, K.; Song, D.; Chung, D.; Pan, C. Optimization of pressurized liquid extraction of zeaxanthin from Chlorella ellipsoidea. J. Appl. Phycol. 2011, 24, 725-730. [CrossRef]

21. Herrero, M.; Jaime, L.; Martín-Álvarez, P.; Cifuentes, A.; Ibanez, E. Optimization of the extraction of antioxidants from Dunaliella salina microalga by presurized liquids. J. Agric. Food Chem. 2006, 54, 5597-5603. [CrossRef] [PubMed]

22. Plaza, M.; Santoyo, S.; Jaime, L.; García-Blairsy, G.; Herrero, M.; Señoráns, F.; Ibazez, E. Screening for bioactive compounds from algae. J. Pharm. Biomed. Anal. 2010, 51, 450-455. [CrossRef] [PubMed]

23. Anaëlle, T.; Serrano Leon, E.; Laurent, V.; Ibanez, E.; Mendiola, J.; Stéphane, C.; Nelly, K.; La Barre, S.; Luc, M.; Stiger-Pouvreau, V. Green improved processes to extract bioactive phenolic compounds from brown macroalgae using Sargassum muticum as model. Talanta 2013, 104, 44-52. [CrossRef] [PubMed]

24. Schmid, M.; Stengel, D. Intra-thallus differentiation of fatty acid and pigment profiles in some temperate fucales and laminariales. J. Phycol. 2015, 51, 25-36. [CrossRef] [PubMed]

25. Agatonovic-Kustrin, S.; Morton, D.; Ristivojevic, P. Assessment of antioxidant activity in Victorian marine algal extracts using high performance thin-layer chromatography and multivariate analysis. J. Chromatogr. A 2016, 1468, 228-235. [CrossRef] [PubMed]

26. Pinteus, S.; Silva, J.; Alves, C.; Horta, A.; Fino, N.; Rodrigues, A.; Mendes, S.; Pedrosa, R. Cytoprotective effect of seaweeds with high antioxidant activity from the Peniche coast (Portugal). Food Chem. 2017, 591-599. [CrossRef] [PubMed] 
27. Tenorio-Rodriguez, P.; Murillo-Álvarez, J.; Campa-Cordova, Á.; Angulo, C. Antioxidant screening and phenolic content of ethanol extracts of selected Baja California macroalgae. J. Food Sci. Technol. 2017, 54, 422-429. [CrossRef] [PubMed]

28. Kosanic, M.; Rankovic, B.; Stanojkovic, T. Biological activities of two macroalgae from Adriatic coast of Montenegro. Saudi J. Biol. Sci. 2015, 22, 390-397. [CrossRef] [PubMed]

29. Abdelhamid, A.; Jouini, M.; Amor, H.; Mzoughi, Z.; Dridi, M.; Said, R.; Bouraoui, A. Phytochemical Analysis and Evaluation of the Antioxidant, Anti-inflammatory, and Antinociceptive Potential of Phlorotannin-Rich Fractions from Three Mediterranean Brown Seaweeds. Mar. Biotechnol. 2018, 20, 60-74. [CrossRef] [PubMed]

30. Kellogg, J.; Lila, M. Chemical and in vitro assessment of Alaskan coastal vegetation antioxidant capacity. J. Agric. Food Chem. 2013, 61, 11025-11032. [CrossRef] [PubMed]

31. Parys, S.; Kehraus, S.; Krick, A.; Glombitza, K.-W.; Carmeli, S.; Klimo, K.; Gerhauser, C.; Konig, G. In vitro chemopreventive potential of fucophlorethols from brown alga Fucus vesiculosus L. by anti-oxidant activity and inhibition of selected cytochrome P450 enzymes. Phytochemistry 2010, 71, 221-229. [CrossRef] [PubMed]

32. Celenk, F.; Ozkaya, A.; Sukatar, A. Macroalgae of Izmir Gulf: Dictyotaceae exhibit high in vitro anti-cancer activity independent from their antioxidant capabilities. Cytotechnology 2016, 68, 2667-2676. [CrossRef] [PubMed]

33. Rodriguez-Meizoso, I.; Jaime, L.; Santoyo, S.; Cifuentes, A.; García-Blairsy, G.; Señoráns, F.; Ibanez, E. Pressurized fluid extraction of bioactive compounds from Phormidium species. J. Agric. Food Chem. 2008, 56, 3517-3523. [PubMed]

34. Moubayed, N.; Al Houri, H.; Al Khulaifi, M.; Al Farraj, D. Antimicrobial, antioxidant properties and chemical composition of seaweeds collected from Saudi Arabia (Red Sea and Arabian Gulf). Saudi J. Biol. Sci. 2017, 24, 162-169. [CrossRef] [PubMed]

35. Kim, H.; Dasagrandhi, C.; Kim, S.; Kim, B.; Eom, S.; Kim, Y. In vitro antibacterial activity of phlorotannins from edible brown algae, Eisenia bicyclis against streptomycin-resistant Listeria monocytogenes. Indian J. Microbiol. 2018, 58, 105-108. [PubMed]

36. El Wahidi, M.; El Amraoui, B.; El Amraoui, M.; Bamhaouda, T. Screening of antimicrobial activity of macroalgae extracts from the Moroccan Atlantic Coast. Ann. Pharm. Fr. 2015, 73, 190-196. [CrossRef] [PubMed]

37. Gupta, S.; Rajauria, G.; Abu-Ghannm, N. Study of the microbial diversity and antimicrobial properties of Irish edible brown seaweeds. Int. J. Food Sci. Technol. 2010, 45, 482-489. [CrossRef]

38. Shanmughapriya, S.; Manilal, A.; Sujith, S.; Selvin, J.; Kiran, G.; Natarajaseenivasan, K. Antimicrobial activity of seaweeds extracts against multiresistant pathogens. Ann. Microbiol. 2008, 58, 535-541. [CrossRef]

39. Shannon, E.; Abu-Ghannm, N. Antibacterial derivatives of marine algae: An overview of pharmacological mechanisms and applications. Mar. Drugs 2016, 14. [CrossRef] [PubMed]

40. Pérez, M.; Falqué, E.; Domínguez, H. Antimicrobial action of compounds from marine seaweed. Mar. Drugs 2016, 14, 52. [CrossRef] [PubMed]

41. Castejón, N.; Luna, P.; Señoráns, F. Ultrasonic removal of mucilage for pressurized liquid extraction of omega-3 rich oil from chia seeds (Salvia hispanica L.). J. Agric. Food Chem. 2017, 65, 2572-2579. [CrossRef] [PubMed]

42. Oliveira, R.; Oliveira, V.; Aracava, K.; da Costa Rodrigues, C. Effects of the extraction conditions on the yield and compsition of rice bran oil extracted with ethanol-A response surface approach. Food Bioprod. Process 2012, 90, 22-31. [CrossRef]

43. Sánchez-Camargo, A.; Pleite, N.; Mendiola, J.; Cifuentes, A.; Herrero, M.; Gilbert-López, B.; Ibanez, E. Development of green extraction processes for Nannochloropsis gaditana biomass valorization. Electrophoresis 2018. [CrossRef] [PubMed]

44. Gilbert-López, B.; Barranco, A.; Herrero, M.; Cifuentes, A.; Ibáñez, E. Development of new green processes for the recovery of bioactives from Phaeodactylum tricornutum. Food Res. Int. 2017, 99, 1056-1065. [CrossRef] [PubMed]

45. Paul, A.; Frederich, M.; Megido, R.; Alabi, T.; Malik, P.; Uyttenbroeck, R.; Francis, F.; Blecker, C.; Haubruge, E. Insect fatty acids: A comparison of lipids from three Orthopterans and Tenebrio molitor L. larvae. J. Asia-Pac. Entomol. 2017, 20, 337-340. [CrossRef] 
46. Milicevic, D.; Varanic, D.; Masic, Z.; Parunovic, N.; Trbovic, D.; Nedeljkovic-Trailovic, J.; Petrovic, Z. The role of total fats, saturated/unsaturated fatty acis and chloesterol content in chicken meat as cardiovascular risk factors. Lipid Health Dis. 2014, 13, 42. [CrossRef] [PubMed]

47. Fats and fatty acids in human nutrition. Report of an expert consultation. FAO Food Nutr. Pap. 2010, 91, $1-166$.

48. Miller, L.; Berger, T. Bacteria identification by gas chromatography of whole cell fatty acids. Hewlett Packard Appl. Note 1985, 228, 241.

49. Saha, S.; Uma, L.; Subramanian, G. Nitrogen stress induced changes in the marine cyanobacterium Oscillatoria willei BDU 130511. FEMS Microbiol. Ecol. 2003, 45, 263-272. [CrossRef]

50. Brand-Williams, W.; Cuvelier, M.E.; Berset, C. Use of a free radical method to evaluate antioxidant activity. Lebens. Wiss. Technol. 1995, 28, 25-30. [CrossRef]

(C) 2018 by the authors. Licensee MDPI, Basel, Switzerland. This article is an open access article distributed under the terms and conditions of the Creative Commons Attribution (CC BY) license (http://creativecommons.org/licenses/by/4.0/). 